\title{
Pesticide in Soil and Rice Crop from North of Iran: Concentration and Risk Assessment
}

\author{
Fatemeh Ghanbaria,*, Seyed Masoud Monavarib, Maryam Kiani Sadrc, Razieh Rahimib, \\ Hanieh Mirbolookia
}

a Environmental Research Institute, Academic Center for Education, Culture and Research (ACECR), Rasht, Iran

${ }^{b}$ Department of Environment, Faculty of Environment and Energy, Science and Research Branch, Islamic Azad University,

Tehran, Iran

${ }^{c}$ Department of Environment, School of Basic Science, Islamic Azad University Hamedan Branch, Hamedan, Iran

\section{A R T I C L E I N F O}

Received: 18 June 2019

Revised: 16 July 2019

Accepted: 25 August 2019

Available online: 26 August 2019

\section{K E Y W O R D S}

\section{Diazinon}

Pesticide

Organophosphorous

Cereals

Hazard quotient

Health risk

\begin{abstract}
A B S T R A C T
Rice is a major diet and staple food in Iran. The most common organophosphorus pesticide used in rice paddies of this area is diazinon. The objective of this research is to determine the concentration of diazinon in soil and rice grains and specify health risk assessment of diazinon in rice when marketed. 30 mixed samples were collected from paddies. High Performance Liquid Chromatography was used to distinguish diazinon pesticide in soil and rice. The results show that diazinon was detected in 96.66 percent of the total samples. The average level of this diazinon in rice was $0.4 \pm 0.43\left(\mathrm{mg} / \mathrm{kg}^{-1}\right)$ three months after harvesting. There was a significant correlation between diazinon concentration of rice grains in all samples $(\mathrm{P}<0.05)$. Also, the average level of diazinon in soil was $0.132 \pm 0.092\left(\mathrm{mg} / \mathrm{kg}^{-1}\right)$. There was no significant difference between the average diazinon concentration in the soil of five zones $(\mathrm{P}>0.05)$. The result indicates that this amount is higher than the MRLs allowed by the European Union and Iran. Target Hazard Quotient was applied to assess human health risk for adults, women and children. Although estimated THQ for all target population is less than 1 that can be a slight non-carcinogen health risk for human.
\end{abstract}

\section{GRA P H I C A L ABS T RACT}

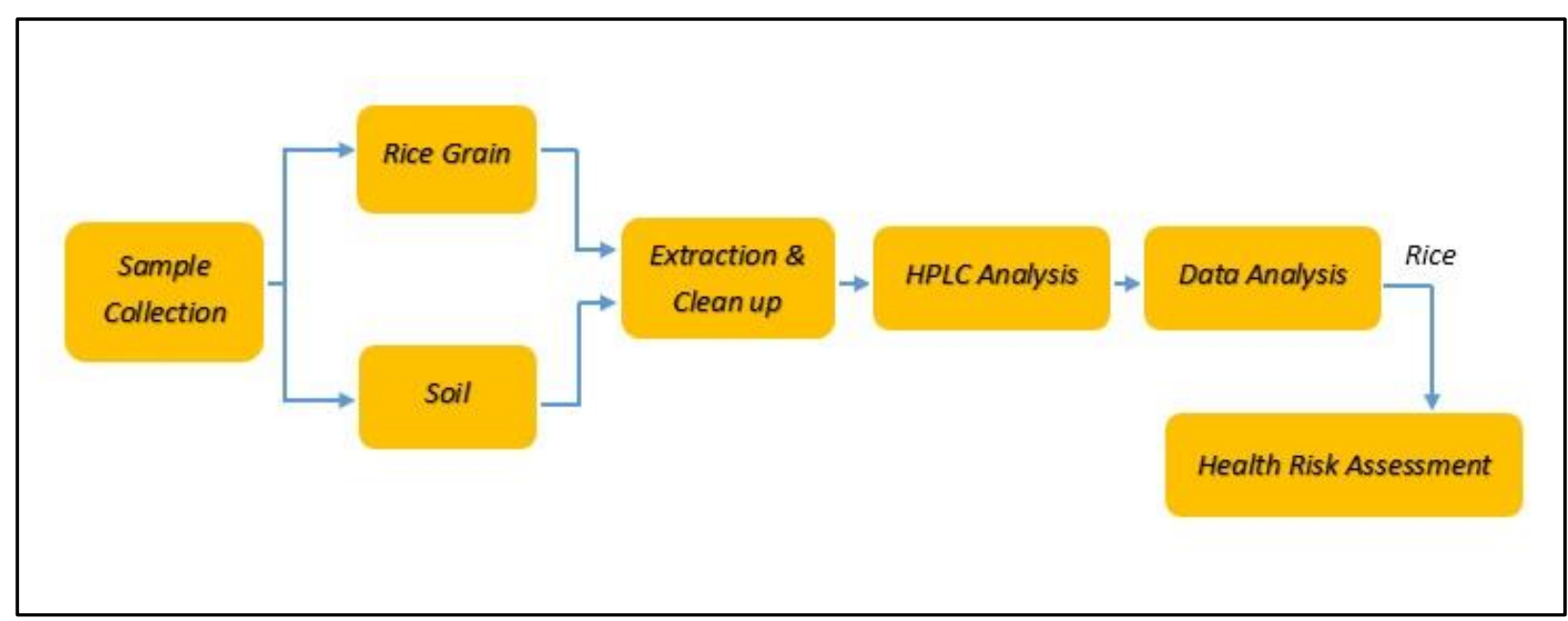

* Corresponding author's E-mail address: ft.ghanbari@gmail.com 


\section{Introduction}

Pests make remarkably food losses, therefore; the control of pests is substantial to achieve food security [1,2]. Pesticides are widely applied in agricultural production to bridle pests including invertebrates, vertebrates and weeds to increase crops quantity and protect high product quality [1]. The application of pesticides for yield preservation is depending on increasing world population and the request for more agricultural production [3]. To address the health related issues of these chemicals, pesticides composed of organochlorine compounds which are mostly prohibited or partially used in most developing countries $[4,5]$ as Iran. So, organophosphorus (OP) pesticides are used high levels in farm lands. There are 200 OP pesticides that have been formulated into various products which consumed in agriculture, industrial zone and rural district $[6,7]$.

Organophosphorus pesticides prevent cholinesterase enzyme. Inhibiting acetylcholinesterase causing to death usually by asphyxiation [7,8]. Pesticides are produced under very strict legislation processes with very little impact on mammals and the environment but because of a high degree of toxicity they can accumulated in agricultural crops and create a health risk for human [9-11]. To reduce the exposure of human to adverse or intakes of pesticides and improve agricultural management, some countries and international organizations have determined the Maximum Residue Limits (MRLs) for foodstuffs. MRL is an indicator of contravention of agricultural act [3, 12-14]. Also, pesticide can transport from agricultural lands and penetrate into different water resources depending on their own characteristic and environmental parameters $[15,16]$. So, because of the widespread application of pesticides, their residues are found in different environmental resources, such as soil and water [17-19].

Rice is an important part of major diet and staple food in Iran as it is a significant source of carbohydrate. Rasht is the southern part of Caspian Sea. The most cultivation of rice in the country is related to this township. Also the most common pesticide used in rice paddies of this area is diazinon. Diazinon is an organophosphorus pesticide with medium resistance which may lead physiological defects. Diazinon poses a risk to humans by affecting acetylcholinesterase enzyme [8]. This pesticide is used against Chilo Suppressalis in rice paddies. Chilo Suppressalis is the most important pest of rice field. This compound is a kind of Organophosphorus which has medium resistance in the environment and cause adverse effect on public health [20].

The objective of this research is to determine the concentration of diazinon in soil and rice grains and assess the health risk of diazinon pesticide residue in rice for adults, women and children.

\section{Experimental}

\section{Sample Collection}

The study area is the rice paddies located in Guilan Province, north of Iran. Geographically, the area is divided into five main zones: north, south, east, west and central parts. According to Figure 1, six spots were determined in each zone and three soil and rice grain samples were collected from each spot. Finally, each three samples were mixed together to prepare one sample. Each mixed sample was packed in a polyethylene bag, labeled and stored at $4{ }^{\circ} \mathrm{C}$. The samples were then transported to the Environmental Research Institute laboratory, Rasht. A total of 30 soil and 30 rice grain samples were collected from the paddies during harvesting seasons from August early September 2014. Sometimes, liquid pesticide is sprayed until the last 2 weeks before harvesting. Therefore, to calculate human health risk assessment in this study, rice samples were kept to analyze when the rice product is ready to present for selling in the market. The analysis 
for rice was done in November.

Figure 1. Study area map showing location of sampling site

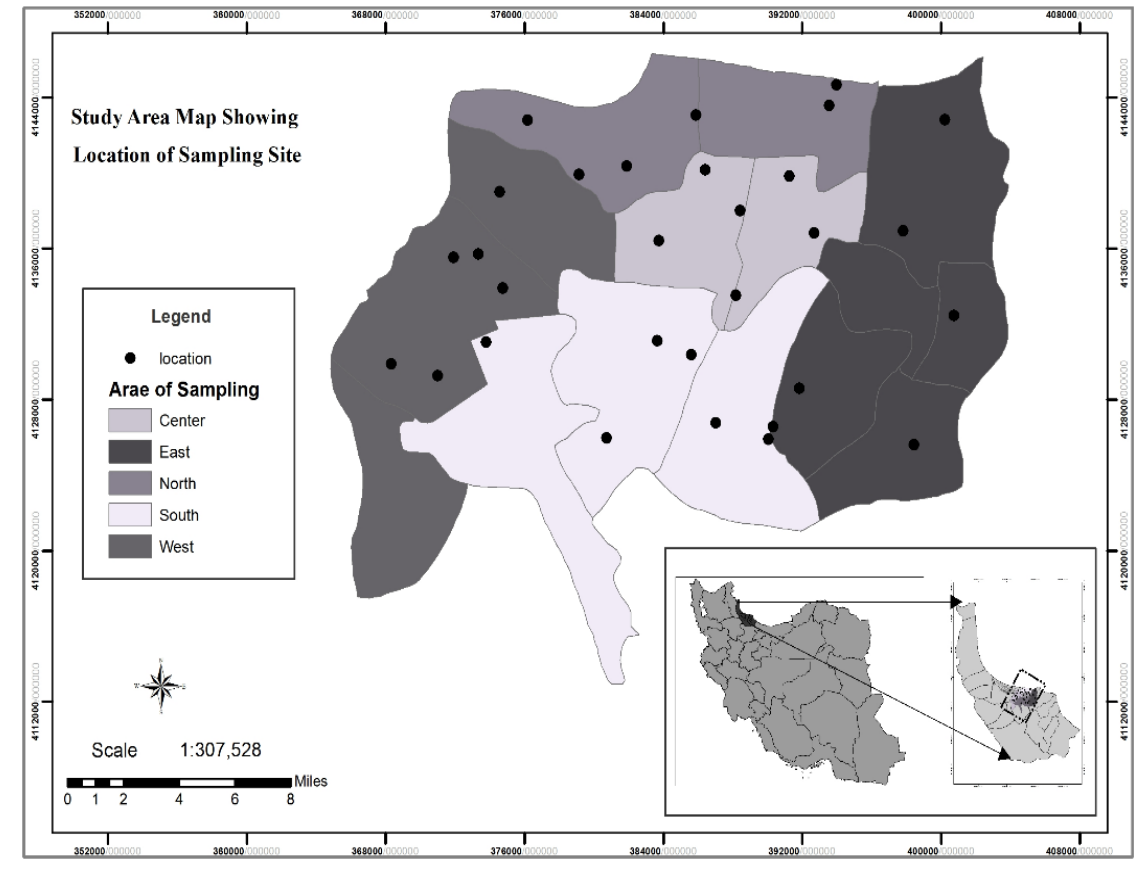

\section{Extraction and clean-up procedure}

At first, the soil samples were dried at environment temperature for two days and passed through the sieve. Methanol and lactic acid (1\% Vol) added to $10 \mathrm{~g}$ of each soil sample for 2 minutes. Then, $\mathrm{NaCl}$ an $\mathrm{CaCl}_{2}$ were added to the solution. The solution was combined to $100 \mathrm{~mL}$ of $\mathrm{HCl}$ and shaken. After that, it was centrifuged for five minutes. So, the dichloromethane phase was disassembled and the solvent was distilled. Then $0.5 \mathrm{~mL}$ of mobile phase $(60 \%$ methanol, 30\% water, 5\% acetonitrile and $5 \%$ tetrahydrofuran) was added to it and 20 $\mu \mathrm{L}$ was injected into the High Performance Liquid Chromatography (HPLC). The injection was repeated three times for each sample.

Also the rice samples were dried and then the whole shells were separated from rice grains two times, and then milled. Then $5 \mathrm{~g}$ sample was watered and placed in a centrifuge for $4 \mathrm{~min}$. The sample was put in a Soxhlet extractor and made up to $50 \mathrm{~mL}$ volume. Petroleum ether was used for the extraction process which was carried out for 4 h. Upon evaporation, the residue was dissolved in methanol. In the final step, each sample was injected to High Performance Liquid Chromatography (HPLC). The injections were repeated three times for each sample.

\section{HPLC analysis}

The HPLC system (HP-Algilent) was equipped with a Diode Array (DA) detector. A C18 Reverse Phase analytical column was used and maintained at $25{ }^{\circ} \mathrm{C}$ in a column oven. The mobile phase, which is a combination of $80 \%$ methanol, $15 \%$ distilled water and 5\% acetonitril was filtered and allowed to run at $0.8 \mathrm{~mL} / \mathrm{min}$ flow rate. Prior to the HPLC analysis, the samples were passed through $254 \mathrm{~nm}$ filters and were manually injected into the HPLC system each time. The distinction of diazinon was carried out by reconciling retention times in samples to peak times in the original analytical standards $[21,22]$. 


\section{Health risk assessment}

In this study, health risk assessment was determined according to diazinon pesticide residue detected in rice after storage and the time of consumption. To assess human health risk of diazinon residue in rice, Target Hazard Quotient (THQ) was used. THQ was calculated based on the USEPA standard method of estimating the risk of non-carcinogenic effects by dividing Estimated Daily Intake (EDI) to Reference Dose (RfD). THQ was determined in accordance with methods by previous researchers [23-25] and used to determine health risk in three target populations: adults, women and children, according to the following and equations 1 and 2:

$$
\begin{aligned}
& T H Q=\frac{\mathrm{EDI}}{\mathrm{RfD}} \\
& E D I=\frac{C F \times I R \times E F \times E D}{B W \times T A}
\end{aligned}
$$

Where $\mathrm{CF}$ is residual pesticide concentration $\left(\mathrm{mg} / \mathrm{kg}^{-1}\right), \quad$ IR is food consumption rate $(\mathrm{kg} /$ day), $\mathrm{EF}$ is exposure frequency (days/year), ED is exposure duration (years). In addition, BW is average body weight and AT is average exposure time for non-carcinogens effect (EF×ED) [26].

The characteristics of the target population are shown in Table 1.

The THQ index of more than 10 indicated very high hazard for consumers. The index of more than 1 indicated high hazard for human health risk. When the index is between 0.1 and 1 indicated low hazard for consumers. Also, the index of less than 0.1 indicated no hazard for human health.

The data analyses were performed with SPSS version 16 . One sample $\mathrm{T}$ test analysis and one-way ANOVA $(\mathrm{P}>0.05)$ were accomplished through SPSS. Also Arc-GIS software version 10.2 was used for locating of each station and identifications of site.

\section{Results and discussion}

\section{Level of diazinon in rice crop}

Diazinon is the most prevalent source of OP pollution in the study area. The results showed that diazinon pesticide was detected in $96.66 \%$ of the total samples of rice grains. The range of diazinon in the study area was 0.0 to $1.9\left(\mathrm{mg} / \mathrm{kg}^{-1}\right)$ in rice grains while the average level in rice samples was $\left(0.4 \pm 0.43 \mathrm{mg} / \mathrm{kg}^{-1}\right)$.

There was a significant difference between the average diazinon concentration in the five zones $(\mathrm{P}<0.05)$. In addition, there was a significant correlation between diazinon concentration in rice grains in all samples $(\mathrm{P}<0.05)$. The results indicated that the highest average of diazinon residue was observed in the central zone while the least concentration was observed in the eastern zone.

Table 1. Characteristics of Target population for estimating THQ

\begin{tabular}{ccccc}
$\begin{array}{c}\text { Target population } \\
\text { Adults }\end{array}$ & $\begin{array}{c}\text { IR } \\
\text { (kg/day) }\end{array}$ & $\begin{array}{c}\text { ED } \\
\text { (years) }\end{array}$ & $\begin{array}{c}\text { BW } \\
(\mathrm{kg})\end{array}$ & $\begin{array}{c}\text { EF } \\
\text { (day/year) }\end{array}$ \\
$\begin{array}{c}\text { Women } \\
\text { W }\end{array}$ & 0.114 & 30 & 65 & 70 \\
$\begin{array}{c}\text { (14 to } 45 \text { years old) } \\
\text { Children }\end{array}$ & & 14 & 35 & 353 \\
$(1$ to 14 years old $)$ & & & & \\
\hline
\end{tabular}


These findings show that pesticide used among farmers in the study area are not the same. The average concentrations of diazinon residue in the different zones summarized in Table 2. Also, the average amount of diazinon residue in rice samples of each station are shown in Table 2 and Figure 2.

The results indicated that the average amounts of diazinon residue in rice grains in the zones were higher than that of MRLs allowed by the European Union [27]. Only nine out of thirty samples were the residues of diazinon found to be less than the EU's MLRs. In addition, the mean pesticide residue in the study area was detected to be also higher than the MRLs presented by the EU. Also the average amount of diazinon residue in rice grains is higher than Maximum diazinon residue limit in cereals allowed by Iran $(0.2$ $\mathrm{mg} / \mathrm{kg}$ ).

Table 2. The average of diazinon residue in rice samples of the study area

\begin{tabular}{cccccc} 
zone & $\begin{array}{c}\text { Number of } \\
\text { multiplex samples }\end{array}$ & Range $(\mathrm{mg} / \mathrm{kg})$ & $\begin{array}{c}\text { Mean } \pm \mathrm{SD} \\
(\mathrm{mg} / \mathrm{kg})\end{array}$ & $\begin{array}{c}\text { Level of } \\
\text { significant }\end{array}$ & $\begin{array}{c}\text { EU MRL } \\
(\mathrm{mg} / \mathrm{kg})\end{array}$ \\
West & 6 & $0.006-0.921$ & $0.316 \pm 0.395$ & 0.004 & \\
East & 6 & $0.007-0.711$ & $0.221 \pm 0.229$ & 0.008 & \\
North & 6 & $0.004-0.896$ & $0.293 \pm 0.349$ & 0.003 & 0.01 \\
South & 6 & $0.0 .47-0.801$ & $0.540 \pm 0.260$ & $\mathrm{P}<0.001$ & \\
Center & 6 & $\mathrm{ND}-1.903$ & $0.628 \pm 0.656$ & 0.001 & \\
Average & 30 & $0.221-0.628$ & $0.4 \pm 0.43$ & - & \\
\hline
\end{tabular}
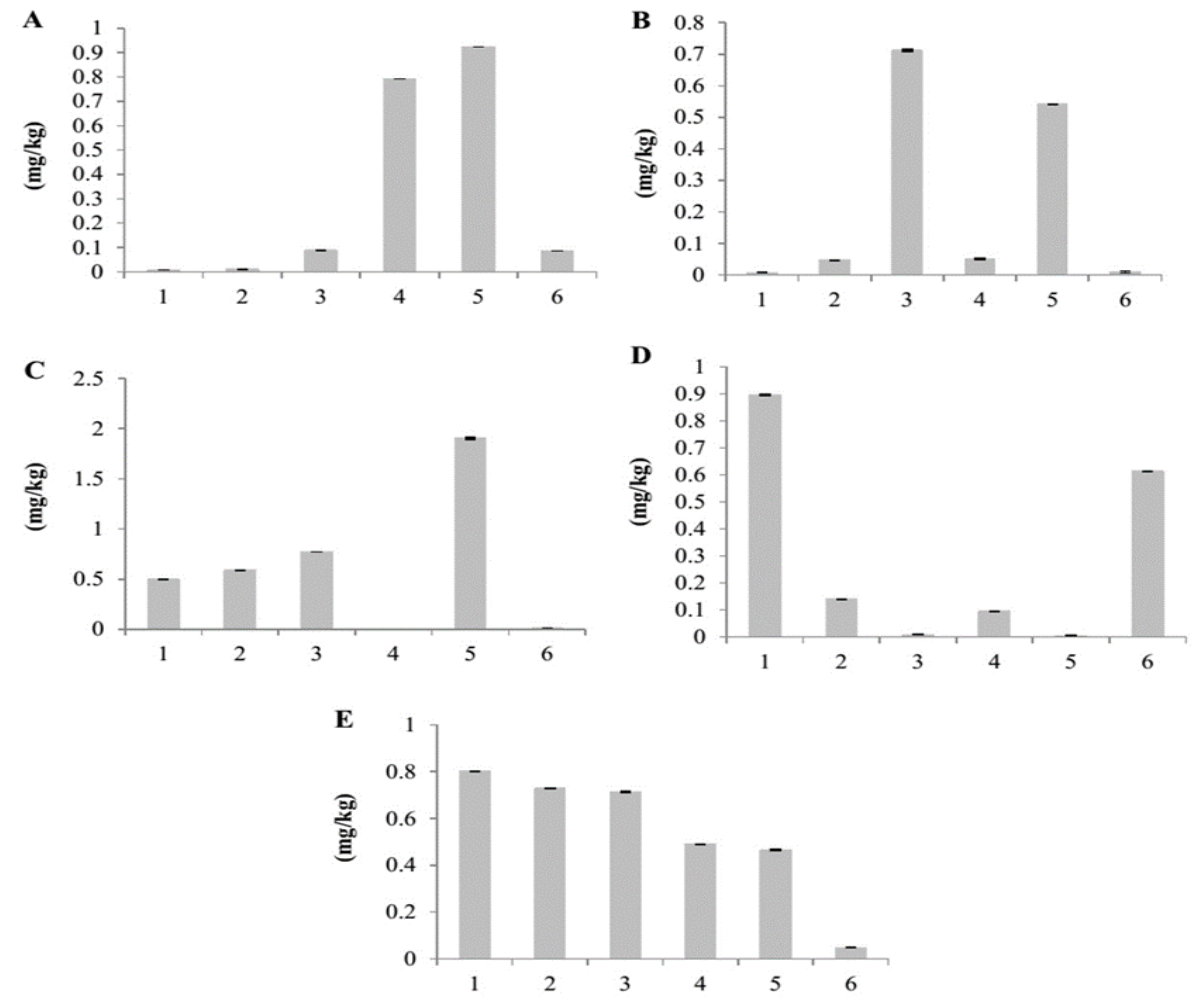

Figure 2. The average amount of diazinon residue in rice samples of each station. (A), (B), (C), (D) and (E) are the result of diazinon residue of west, east, center, north and south zone, respectively 
In previous studies carried out on market food, the concentrations of organophosphorus pesticide detected were by far less than those reported in this study [17-28,29]. Also detected was that organochlorine pesticides residues in cereals of Turkey were less than the results of this research [30]. According to the current study, the average residue of diazinon in rice samples is $0.4\left(\mathrm{mg} / \mathrm{kg}^{-1}\right)$ while Amirahmadi et al. reported $0.1 \mathrm{mg} / \mathrm{kg}^{-1}$ of diazinon in rice samples collected from Tehran bazar [31]. Similarly, in another study, the OP pesticide of cereal was more than MRL in China [28]. Also in Bangladesh, the residue of organochlorine pesticides in agricultural products was higher than MRL, but OPs were not found or were much less than MRL in samples [17]. Moreover, Golge et al., reported that all detected pesticide of green paper and cucumber were below the EU MRLs in Turkey [32]. The differences between current study and others show that much more pesticides are used in Iran. The average concentration of the OP pesticide in the study area is higher than the MRLs allowed by the European Union thus agreeing with a research conducted in Nigeria [1].

\section{Level of diazinon in soil}

The results indicated that the highest and the lowest level of diazinon in soil sample were $0.377 \mathrm{mg} / \mathrm{kg}$ and $0.012 \mathrm{mg} / \mathrm{kg}$, respectively. There was no significant difference between the average of diazinon concentration in the soil of five zones $(\mathrm{P}>0.05)$. The concentrations of diazinon residue in soil samples summarized in Table 3. Also Figure 3, showed the concentration of diazinon residue in each station.

The difference in concentration of diazinon in soil samples declared that each farmer uses different amount of granular and liquid diazinon. The result of a same study showed that pesticide stability in soil is extremely dependent on the concentration of pesticide used, the number of spraying, the time of use, the weather condition and the soil environment [33]. In China, the concentration of pesticides in soil samples varied from 0.001 to $3.52\left(\mathrm{mg} / \mathrm{kg}^{-1}\right)$, which is even more than the concentration of pesticides in some zones of current study [34]. In other previous studies on soil, the concentrations of the detected pesticide were by far less than those described in this research [3-35,36]. Also, the results of the same studies indicated that pesticides are washed from soil into the surface and groundwater [37], moreover absorbing by plant [38].

In the current study, the average residue concentration of diazinon in the rice samples $(0.4 \mathrm{mg} / \mathrm{kg})$ was higher than that of the soil samples $(0.132 \mathrm{mg} / \mathrm{kg})$. Similar results were revealed by Liu et al., Also, there was no significant relationship between pesticide concentration in soil and crop samples [3].

Table 3. The average of diazinon residue in soil samples of the study area

\begin{tabular}{ccccc} 
zone & $\begin{array}{c}\text { Number of } \\
\text { multiplex samples }\end{array}$ & Range $(\mathrm{mg} / \mathrm{kg})$ & $\begin{array}{c}\text { Mean } \pm \text { SD } \\
(\mathrm{mg} / \mathrm{kg})\end{array}$ & $\begin{array}{c}\text { Level of } \\
\text { significant }\end{array}$ \\
West & 6 & $\mathrm{ND}-0.192$ & $0.095 \pm 0.064$ & \\
East & 6 & $\mathrm{ND}-0.283$ & $0.136 \pm 0.092$ & \\
North & 6 & $\mathrm{ND}-0.239$ & $0.153 \pm 0.065$ & - \\
South & 6 & $0.012-0.377$ & $0.170 \pm 0.135$ & \\
Center & 6 & $\mathrm{ND}-0.132$ & $0.097 \pm 0.050$ & \\
Average & 30 & $0.012-0.377$ & $0.132 \pm 0.092$ & 0.073 \\
\hline
\end{tabular}



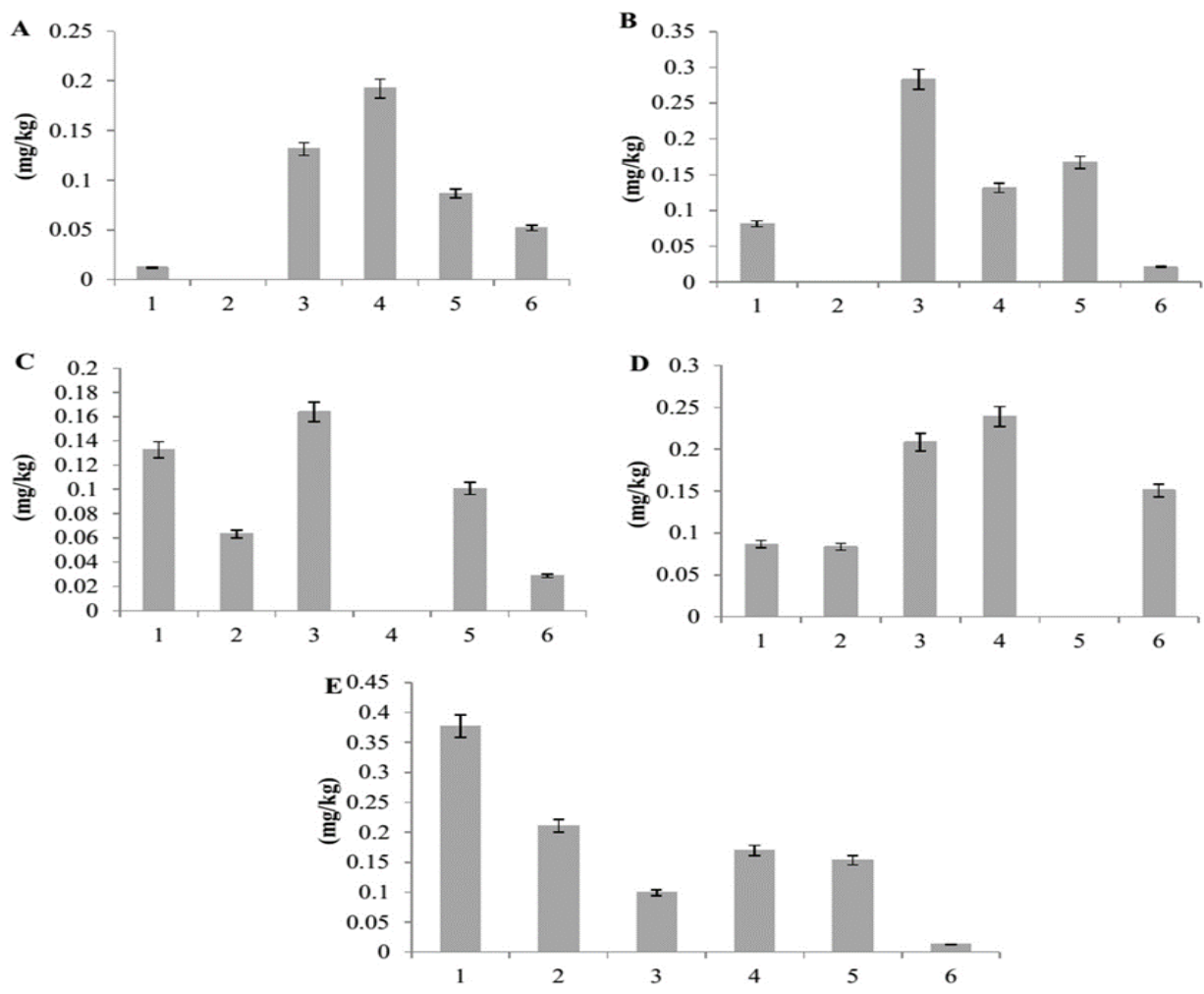

Figure 3. The average amount of diazinon residue in soil samples of each station. (A), (B), (C), (D) and (E) are the result of diazinon residue of west, east, center, north and south zone, respectively

\section{Human health risk assessment}

Rice consumption has been shown to be one of the primary sources of human exposure to OPs especially diazinon. To better understand the effect of diazinon on human health, Target Hazard Quotient (THQ) was evaluated. To comprehensively evaluate risk exposure to noncarcinogens, THQ was calculated for three groups in the population. The results showed that EDIs was calculated for adults, women and children as 0.0006, 0.0007 and 0.0013 milligram per kilogram body weight per day, respectively. According to Figure 4, THQ were calculated as $0.24,0.28$ and 0.52 for adults, women and children, respectively. Although the estimated THQ for the target population is between 0.1 and 1, there can be a slight noncarcinogen health risk for humans. These findings showed that diazinon pesticide via consumption of rice has the highest effect on children than in the other groups. So, hazard indices are at level 2 for non-carcinogens with low hazard for the target populations.

The results of THQ highlighted that although there is a slight health risk for adults, women and children through eating rice, the amount of pesticide used for agricultural products should be considered. However, it could have a more health effect on children. Because a child has lower body weight than a mature, which higher intake of pesticide is expected by children than that by matures $[39,40]$. The results of risk assessment for the target population in fruits and fish in Egypt also showed that THQ for children is higher than the other groups [41]. Moreover, Valcke et al reported that the health risk of consumption of pesticide in fruits and vegetables was found for children [42]. Further, the results of health risk assessment for pesticide in peaches declared that the chronic dietary risks were very low for both adults and children in China [43]. Also the results of risk assessment for pesticides in cowpea declared that THQ was less than 1 and there is a slight health risk for consumers [25]. Differently, some 
other researches declared that pesticides in agricultural crops had no health risk for consumers [3-44,45]. However, some studies declared that diazinon decomposes and its concentration reduces in food crops after one month because of moderately persistent and short half-lives $[46,47]$. Therefore, the effect of used pesticide depends on the time between pesticide application and ingestion [4].

Figure 4. Target

Health Quotient for diazinon residue in rice

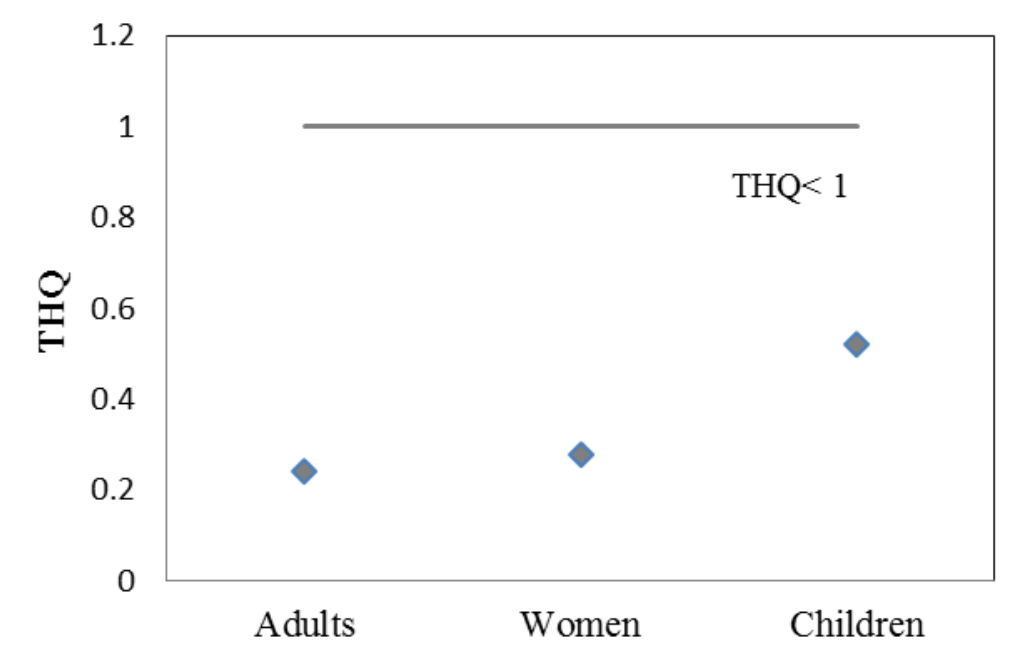

\section{Conclusion}

The present study showed that diazinon pesticide contamination is exhibited in soil and rice samples of rice farms in Rasht Area, Guilan Province, Iran. Also the average amount of diazinon in rice samples is much more than the MRLs allowed by the European Union and the Maximum diazinon residue limit in cereals allowed by Iran. In addition, the average residue concentration of diazinon in rice samples was higher than that of soil samples. Although estimated health risk assessment for all target population is less than 1 that can be a slight non-carcinogen health risk for human in the study area. According to similar studies diazinon decomposes and its concentration reduces in food crops after some months, so storing and consuming after some months could reduce the effect of used pesticide.

\section{Acknowledgment}

The authors wish to thank Science and Research Branch, Islamic Azad University
(Tehran, Iran) and all people who have contributed in this project. Administrative also wish to thank dear Sepideh Ghanbari for her kindness and support during the project.

\section{Disclosure statement}

No potential conflict of interest was reported by the authors.

\section{References}

[1] J.C. Akan, L. Jafiya, Z. Mohammed, F.I. Abdulrahman, Ecosystems, 2013, 3, 5864.

[2] I.B. Iya, T.T. Kwaghe, Int. J. Agric. Res., 2007, 2, 647-650.

[3] Y. Liu, S. Li, Z. Ni, M. Qu, D. Zhong, C. Ye, F. Tang, Sci. Total. Environ., 2016, 542, 620628.

[4] R. Juraske, F. Castells, A. Vijay, P. Muñoz, A. Antón, J. Hazard. Mater., 2009, 165, 683689.

[5] Y.B. Yohannes, Y. Ikenaka, A. Saengtienchai, K.P. Watanabe, S.M. Nakayama, M. Ishizuka, Ecotox. Environ. 
Safe., 2014, 106, 95-101.

[6] E.F. Hill, Wildlife toxicology of organophosphorus and carbamate pesticides. Handbook of ecotoxicology, CRC Press, 2003, pp. 281-312.

[7] D.W. Sparling, G. Fellers, Environ. Pollut., 2007, 147, 535-539.

[8] M. Shayeghi, M. Khobdel, F. Bagheri, M. Abtai, J. Pub. Heal. Heal. Res. Instit., 2008, 6, 75-82.

[9] E.H. Abdelgadir, S.E.I. Adam, J. Pharmacol. Toxicol., 2011, 6, 69-75.

[10] D. Ortelli, P. Edder, C. Corvi, Anal. Chim. Acta, 2004, 520, 33-45.

[11] N.A. Zidan, Int. J. Pharmacol., 2009, 5, 5157.

[12] S.I. Ghabbour, Z.H. Zidan, M.H. Sobhy, Z.A. Wafai Mikhail, M.T. Selim, AmericanEurasian J. Agric. \& Environ. Sic., 2010, 12, 177-187.

[13] L. Nasreddine, D. Parent-Massin, Toxicol. Lett., 2002, 127, 29-41.

[14] L.G. Skretteberg, B. Lyrån, B. Holen, A. Jansson, P. Fohgelberg, K. Siivinen, B.H. Jensen, Food Control, 2015, 51, 225-235.

[15] M.J. Cerejeira, P. Viana, S. Batista, T. Pereira, E. Silva, M.J. Valério, A.M. SilvaFernandes, Water Res., 2003, 37, 10551063.

[16] C. Planas, J. Caixach, F.J. Santos, J. Rivera, Chemosphere, 1997, 34, 2393-2406.

[17] M.S. Hossain, M.A.Z. Chowdhury, M.K. Pramanik, M.A. Rahman, A.N.M. Fakhruddin, M.K. Alam, Appl. Water Sci., 2015, 5, 171-179.

[18] A.M. Rodrigues, V. Ferreira, V.V. Cardoso, E. Ferreira, M.J. Benoliel, J. Chromatogr. A, 2007, 1150, 267-278.

[19] X. Zhang, M. Zhang, Sci. Total Environ., 2011, 409, 1949-1958.

[20] M. Banaee, A. Sureda, A.R. Mirvaghefi, K. Ahmadi, Pestic. Biochem. Physiol., 2011, 99, 1-6.

[21] M.A.Z. Chowdhury, S. Banik, B. Uddin, M. Moniruzzaman, N. Karim, S.H. Gan, Int. J. Environ. Res. Public Health, 2012, 9,
3318-3329.

[22] M.S. Hossain, A.N.M. Fakhruddin, M. Alamgir Zaman Chowdhury, M.A. Rahman, M. Khorshed Alam, Int. Food Res. J., 2015, 22, 110-115.

[23] O. Akoto, H. Andoh, G. Darko, K. Eshun, P. Osei-Fosu, Chemosphere, 2013, 92, 6773.

[24] O. Akoto, F. Bismark Eshun, G. Darko, E. Adei, Int. J. Environ. Res., 2014, 8, 403410.

[25] Donkora, P. Osei-Fosu, S. Nyarkoa, R. Kingsford-Adaboha, J. Yaa, A. Okyere, Res. J. Chem. Environ. Sci., 2015, 3, 8-10.

[26] N. Saha, M.R. Zaman, Environ. Monitor. Assess., 2013, 185, 3867-3878.

[27] FAO (Food and Agriculture Organization of the United Nations), Pesticide residues in food-2006. In Report of the Joint Meeting of the FAO Panel of Experts on Pesticide Residues in Food and the Environment and the WHO Core Assessment Group on Pesticide Residues. Rome, Italy: Food and Agricultural Organization. 2006.

[28] Y. Bai, L. Zhou, J. Wang, Food Chem., 2006, 98, 240-242.

[29] M. Juan-Borrás, E. Domenech, I. Escriche, Food Control, 2016, 67, 127134.

[30] G.O. Guler, Y.S. Cakmak, Z. Dagli, A. Aktumsek, H. Ozparlak. Food Chem. Toxicol., 2010, 48, 1218-1221.

[31] M. Amirahmadi, H. Yazdanpanah, S. Shoeibi, M. Pirali-Hamedani, M.O. Gholami, M.F. Mohseninia, F. Kobarfard, Iran. J. Pharm. Res., 2013, 12, 295-302.

[32] O. Golge, F. Hepsag, B. Kabak, Food Chem. Toxicol., 2018, 121, 51-64.

[33] J. Schlosserová, Sci. Total Environ., 1992, 123, 491-501.

[34] J. Sun, L. Pan, Y. Zhan, H. Lu, D.C. Tsang, W. Liu, L. Zhu, Sci. Total Environ., 2016, 544, 670-676.

[35] M. Liu, Y. Yang, X. Yun, M. Zhang, J. Wang, Environ. Earth Sci., 2015, 74, 5001-5008. 
[36] L. Pan, J. Sun, Z. Li, Y. Zhan, S. Xu, L. Zhu, Environ. Sci. Poll. Res., 2018, 25, 4-11.

[37] I.C. Yadav, N.L. Devi, J.H. Syed, Z. Cheng, J. Li, G. Zhang, K.C. Jones, Sci. Total Environ., 2015, 511, 123-137.

[38] M.A. Kamrin, Pesticide profiles: toxicity, environmental impact, and fate. CRC press, 1997.

[39] Y. Jiang, X. Hu, U.J. Yves, H. Zhan, Y. Wu, Ecotox. Environ. safe, 2014, 106, 11-18.

[40] M. Gope, R.E. Masto, J. George, S. Balachandran, Sustain. Cities Soc., 2018, 38, 616-626.

[41] P.B. Tchounwou, B.A. Ashour, C. Moreland-Young, D.A. Ragheb, A.A. Romeh, E.A. Goma, J.C. Assad, Int. J. Mol. Sci., 2003, 3, 1082-1094.

[42] M. Valcke, M.H. Bourgault, L. Rochette, L.
Normandin, O. Samuel, D. Belleville, D. Phaneuf, Environ. Int., 2017, 108, 63-74.

[43] Z. Li, J. Nie, Z. Yan, Y. Cheng, F. Lan, Y. Huang, A. Li, Regul. Toxicol. Pharmaco.l, 2018, 97, 152-162.

[44] A. Mahmood, R.N. Malik, J.H. Syed, J. Li, G. Zhang, Chemosphere, 2015, 118, 57-64.

[45] Y. Fang, Z. Nie, Y. Yang, Q. Die, F. Liu, J. He, Q. Huang, Environ. Sci. Poll. Res., 2015, 22, 6136-6143.

[46] A.G. Hornsby, D.R. Wauchope, A.E. Herner, Pesticide properties in the environment. Springer Verlag, New York, 1996.

[47] USEPA. Reregistration Eligibility Decision for Diazinon. U.S. Environmental Protection Agency. Office of Pesticide Programs, Washington DC, USA, 2006.

How to cite this manuscript: Fatemeh Ghanbari, Seyed Masoud Monavari, Maryam Kiani Sadr, Razieh Rahimi, Hanieh Mirbolooki, Pesticide in Soil and Rice Crop from North of Iran: Concentration and Risk Assessment, Adv. J. Chem. A, 2020, 3(2), 211-220. 